\title{
Combined immunodeficiency due to LRBA deficiency
}

INSERM

\section{Source}

INSERM. (1999). Orphanet: an online rare disease and orphan drug data base. Combined immunodeficiency due to LRBA deficiency. ORPHA:445018

A rare, genetic, primary immunodeficiency characterized by early onset of recurrent respiratory infections and variable combination of autoimmune disorders, including hemolytic anemia, thrombocytopenic purpura, lymphoproliferative disease, inflammatory bowel disease, colitis, diabetes, arthritis, and dermatitis. Failure to thrive, hepatosplenomegaly and endocrine abnormalities have also been associated. Variable immunologic findings include deficiency of $\mathrm{CD} 4+\mathrm{T}$ regulatory cells, decreased B-cells, and hypog ammag lobulinemia. 